\title{
Total Correction without Cardiopulmonary Bypass of Isolated Left Hemitruncus Arteriosus
}

\author{
Izole Sol Hemitruncus Arteriozusun Kardiyopulmoner Bypass \\ Kullanılmadan Tam Düzeltimi
}

\author{
Muhammet Akyüz, Onur Işık, Mehmet Fatih Ayık, Yüksel Atay \\ Ege University Faculty of Medicine, Department of Cardiovascular Surgery, Izmir, Turkey
}

\begin{abstract}
Hemitruncus is an uncommon congenital defect in which a pulmonary artery (PA) branch originates abnormally from the ascending aorta. Left hemitruncus is less common than a right hemitruncus. In this report, we present an isolated left hemitruncus in a neonate who showed progressive respiratory distress in the second week following delivery. At 21 days of age, the patient underwent total surgical correction of the defect, during which a direct end-to-side anastomosis to main PA without conduit interposition was employed. After a prolonged intubation period with pneumonia, the patient was discharged from hospital on the $17^{\text {th }}$ postoperative day.

Keywords: Hemitruncus, isolated, neonate
\end{abstract}

\section{ÖZ}

Hemitrunkus pulmoner arter (PA) dallarından birinin çוkan aortadan kaynaklandığı nadir bir konjenital anomalidir. Sol hemitrunkus sağ hemitrunkusa göre daha az görülmektedir. Bu makalede doğumu takiben ikinci haftada ilerleyici solunum sıkıntısı ortaya çıkan yenidoğanda izole sol hemitrunkus olgusu sunuldu. Yirmi bir günlük hastada kondüit gereksinimi olmadan ana PA'ya uç-yan anastomoz ile tam düzeltim sağlandı. Pnömoni nedeniyle uzun entübasyon süresi sonrası, hasta postoperatif 17 . günde taburcu edildi.

Anahtar Kelimeler: Hemitrunkus, izole, yenidoğan

\section{Introduction}

Hemitruncus is an uncommon congenital defect, accounting for only $0.12 \%$ of all congenital cardiac defects, in which a pulmonary artery (PA) branch originates abnormally from the ascending aorta (1). Diagnosis and surgery at very early ages are important to prevent irreversible vascular pulmonary disease. This defect should be suspected in newborns with heart failure and increased left pulmonary flow, as in the present case. We present herein a case of a neonate with isolated left hemitruncus, in which surgical correction without cardiopulmonary bypass (CPB) was performed successfully.

\section{Case Report}

A 21-day-old female neonate with left hemitruncus arteriosus was referred to our hospital for surgical evaluation. In the second week of life, the neonate presented with progressively worse tachypnea, tachycardia, and grade 4/6 systolic murmur in the mesocardium. At the time of diagnosis, the patient was a 13-day-old newborn female and weighed $3.1 \mathrm{~kg}$. The chest x-ray showed cardiomegaly with increased vascularity of the left lung compared to the right lung. The diagnosis was first made by means of echocardiography and confirmed with cardiac catheterization thereafter. Echocardiography showed moderate dilatation in both ventricles and a continuity between the aorta 
and left PA. Pulmonary angiography revealed the right PA arising from the main PA, with the absence of the left PA; aortography revealed the left PA arising from the ascending aorta (Figure 1). Repair was performed through a standard median sternotomy approach. Repair was planned without using CPB. The main pulmonary artery (MPA), branch PA, and aorta were mobilized. The anomalous PA was looped. The left PA was clamped and divided from its origin at the ascending aorta, and the aortic end was repaired directly. The side-biting clamp was applied to MPA and hemodynamic instability did not develop. The MPA was opened after the application of a side-biting clamp and end-toside anastomosis was created between the anomalous PA and the MPA (Figure 2). The patient underwent successful surgical reimplantation of the left PA to the MPA. A postoperative echocardiography demonstrated normal flow to the left PA.

The patient developed postoperative pneumonia that required prolonged ventilation (10 days). The patient was discharged from hospital on the 17th postoperative day.

\section{Discussion}

Hemitruncus is an uncommon congenital defect in which a pulmonary artery branch originates abnormally from the ascending aorta (2). The pathology is frequently associated with other cardiac malformations, including patent ductus arteriosus (PDA), tetralogy of Fallot, PDA, aortopulmonary window, arcus anomalies, and double outlet ventricle. Thus, it is extremely rare for hemitruncus to be observed as an

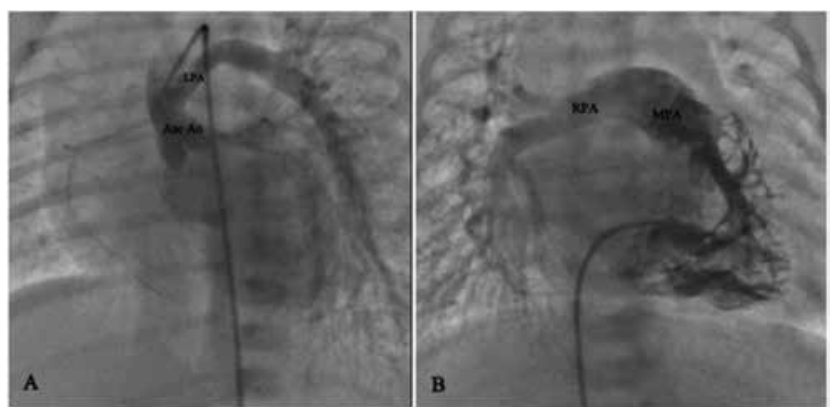

Figure 1. A) Aortography; the left pulmonary artery is clearly seen to originate from the ascending aorta (left hemitruncus), B) Right ventriculography: main pulmonary artery, right pulmonary artery, and absence of left pulmonary artery are visualized

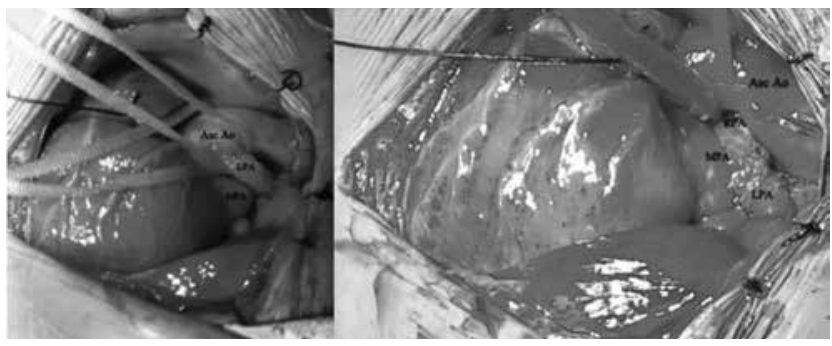

Figure 2. Operative view of the left pulmonary artery. A) preoperative, B) postoperative

Asc Ao: Ascending aorta, MPA: Main pulmonary artery, LPA: Left pulmonary artery, RPA: Right pulmonary artery isolated defect $(3,4)$. The anomaly is five to six times more common in the right branch than in the left branch (1).

The clinical picture of hemitruncus involves recurrent respiratory distress, tachypnea, dyspnea, heart murmurs, and heart failure, which appear within a week or less following birth (5). Infants with hemitruncus usually display large leftto-right shunt with no accompanying cyanosis. The defect should particularly be examined in neonates exhibiting heart failure in the absence of any intracardiac pathology by using echocardiography (4). On their own, an evaluation of patient history and of physical examination, electrocardiography, and chest radiography results are not sufficient to establish diagnosis. Echocardiography is both important and useful for identifying anomalies associated with the ascending aorta (6). An initial diagnosis is usually performed using two-dimensional color Doppler echocardiography; however, this method fails to detect and identify up to $15 \%$ of cases (5). A definite diagnosis is generally established with cardiac catheterization, which also provides important information for surgical planning. In our case, the defect was identified through transthoracic echocardiography; we then performed cardiac catheterization to demonstrate the associated pathology in our patient.

With advanced age, the incidence of heart failure and recurrent respiratory tract infections increases in newborns (1). Hemitruncus, which is not surgically treated, is usually fatal, causing death early in infancy as a result of irreversible pulmonary hypertension (7). Surgery at a very early stage is necessary to prevent the development of irreversible pulmonary hypertension in neonate infants.

Surgical repair can be performed either with or without CPB. In infants, the advantage of CPB is that it the enables adequate mobilization of the defective PA. It also facilitates the separation of the pulmonary artery from the ascending aorta, and the reimplantation of the PA (8). However, CPB can induce systemic inflammatory responses; for this reason, surgical techniques that avoid CPB (similar to that which we employed in our patient) should result in fewer CPB-related complications and postoperative pulmonary problems. The literature describes a number of surgical techniques for the reimplantation of the defective pulmonary artery at a location on the main PA posterior to the ascending aorta. These techniques include direct anastomosis, the most commonly employed technique; the interposition of a synthetic tubular prosthesis, which is almost no longer used; and the use of an autologous pericardial patch or aortic flap to create extensions (8).

To decrease the mortality and morbidity rates associated which hemitruncus, caused by heart failure and pulmonary vascular diseases stemming from excessive pulmonary blood pressure, it is essential to diagnose the defect in a timely manner in neonates, to employ effective surgical techniques that do not involve $\mathrm{CPB}$, and to successfully manage the patients during the perioperative and postoperative periods.

\section{Authorship Contributions}


Informed Consent: Consent form was filled out by all participants, Concept: Muhammet Akyüz, Onur Işık, Design: Muhammet Akyüz, Data Collection or Processing: Onur Işık, Analysis or Interpretation: Mehmet Fatih Ayık, Yüksel Atay, Literature Search: Muhammet Akyüz, Onur Işık, Writing: Muhammet Akyüz, Peer-review: Internal peer-reviewed, Conflict of Interest: No conflict of interest was declared by the authors, Financial Disclosure: The authors declared that this study has received no financial support.

\section{References}

1. Kutsche LM, Van Mierop LH. Anomalous origin of a pulmonary artery from the ascending aorta: associated anomalies and pathogenesis. Am J Cardiol 1988; 61: 850-6.

2. Penkoske PA, Castenada, AR, Fyler DC, van Praag R. Origin of pulmonary artery branch from ascending aorta. Primary surgical repair in infancy. J Thorac Cardiovasc Surg 1983; 85: 537-45.

3. Cheng $W$, Xiao Y, Zhong $Q$, Wen R. Anomalous origin of left pulmonary artery branch from the aorta with Fallot's tetralogy. Thorac Cardiovasc Surg 2008; 56: 432-4.

4. Erdem A, Aydemir NA, Demir $\mathrm{H}$, et al. Anomalous origin of one pulmonary artery branch from the ascending aorta: experience of our center. Turk Kardiyol Dern Ars 2010; 38: 411-5.

5. Miyazaki K, Murashita T, Kubota T, Matsuzaki K, Miyazaki YJ, Yasuda K. Neonatal repair of anomalous origin of the right pulmonary artery from the ascending aorta. Acase report and review in the literature. J Cardiovasc Surg 2000; 41: 863-8.

6. Godown J, Baker C, Kuhn N, et al. Delayed repair of hemitruncus in an extremely low birth weight infant. Congenit Heart Dis 2013; 8: 13-6.

7. Smallhorn JF, Anderson RH, McCartney FJ. Two-dimensional echocardiographic assessment of communications between ascending aorta and pulmonary trunk orindividual pulmonary arteries. Br Heart J 1982; 47: 563-72.

8. Corno AF, Festa GP. Congenital heart defects. In: Corno AF (ed). Anomalous pulmonary arteries. Germany, Steinkopff Verlag, 2009; 3: 173-5. 